\title{
Strategies to Increase Travel Attraction of Jaranan Dance Art at Digital Technology Era
}

\author{
Yudiarto Perdana Putra ${ }^{{ }^{*}}$ Bothy Dewandaru ${ }^{2 *}$ Nindi Vaulia ${ }^{3}$ \\ ${ }^{1,2,3}$ Economics Faculty, Kadiri University, Kediri, Jawa Timur, Indonesia \\ *Corresponding author. Email: yudiarto@unik-kediri.ac.id \& bothy@unik-kediri.ac.id
}

\begin{abstract}
This research was made to see how much the utilization of the creative industry in the Kediri City and the development of the local economy, especially in the Jaranan art dance, which has become one of the icons of Kediri City. Through the preservation and development of Jaranan art dance, it will encourage the growth of other creative industries. This research uses qualitative descriptive data analysis method, where this method is used to explain a phenomena that occurs. The results showed that the Jaranan arts had a great appeal in the people of Kediri City. The government also has the seriousness to manage that is by giving the parent number and participating in the event in the Kediri City. Jaranan art dance gives its own charm, so that in every show there are many small traders who sell and the increasing number of Jaranan equipment craftsmen who live from the attraction of Jaranan art. The location of the show is needed with good facilities, as well as a fixed scheduling so that tourists can be comfortable and easy in enjoying Jaranan art dance. Promotional activities through internet social media, and shows use technical materials than can add a modern impression. Jaranan sustainability can be maintained by including in the school curriculum.
\end{abstract}

Keywords: Creative Economy, Cultural Preservation, Jaranan Art Dance.

\section{INTRODUCTION}

In Indonesia, the creative economy is understood as an industry that derives from the use of resource reserves that are not only renewable, even unlimited, namely ideas, ideas, talents or talents, and creativity. Industry can no longer compete in the global market by relying only on price or product quality but must compete based on innovation, creativity, and imagination. According to the Ministry of Commerce (2008), there are several directions from the development of this creative industry, such as the development that focuses more on industries based on (1) creative cultural industries; (2) creative industry, or (3) Intellectual Property Rights such as copyright.

The development of the tourism sector is supported by Presidential Instruction No. 16 of 2005 concerning policies on cultural and tourism development, there are seven policies listed, namely: promotion intensified, accessibility needed, quality of products and services improved, tourism areas developed, marine tourism promoted, human resources enhanced, cultural awareness, and Sapta's charm is cultivated. Local economic development based on performing arts has the potential to make tourism villages based on art. Tourism activities by utilizing local resources began to be developed based on sustainable economic goals, supporting environmental conservation efforts, and improving the welfare of local communities. Strengthening the creative and cultural industries, the government is obliged to encourage the development of territorial networks, and issue policies to support the local economy, so that it will relate between workers, the public and the private sector [1]

Jaranan art dance in Kediri City itself is found in every district and there are quite a number of them. If this 
potential is not utilized by the local government, then the economic impact of Jaranan art dance will gradually disappear like the potential for employment. The government as a policymaker has not maximized the potential of Jaranan dance art as a tourist attraction, Jaranan art dance has only been utilized in the annual activities of Kediri City, but regular and scheduled performances do not yet exist. In Jaranan art dance there is a magical element or can be categorized as dark tourism, the current study highlights aspects of tourist experience which are important for the concept of dark tourism, namely the motivation to visit and benefit from the tourist interpretation [2]. Watching the dark tourism event will tell us that dark tourists are generally motivated by the desire to gain knowledge from aspects of the world that cannot be fully explained [3]. The purpose of this research is to find out the development \& strategy to preserve Jaranan art dance in order to increase tourist visits.

\subsection{Theory Study}

\subsubsection{Connection between Cultural \& Creative Economy}

Ideas are very important economic goods, more important than objects which are often emphasized in most economic models and systems. In a world that experiences physical limitations, the discovery of great ideas, which is also accompanied by millions of small ideas, has kept the economy growing dynamically. The creative economy is closely related to the creative industry, but the creative economy has a broader scope than the creative industry. The creative economy is an ecosystem that has a relationship of interdependence between creative value chains; development environment (nurturance environment); market (market) and archiving. The creative economy is not only related to the creation of economic added value but also the creation of added values socially, culturally and environmentally. Therefore, the creative economy can improve competitiveness and can improve the quality of life of the Indonesian people.

To develop the creative economy, it is believed that collaboration between those who play a role in the creative industry, namely intellectuals, business (business), and government (government) becomes absolute and is a separate prerequisite. Without the collaboration of the three elements, it is feared that the development of the creative economy does not run in harmony, be efficient and overlap[4]. This is because every actor has a significant role, but also requires contributions from various parties. This form of collaboration between scholars, business, and the government is the main step that needs to be formulated (Ministry of Trade, 2008). Cultural Tourism must be a behavior that is involved in tourism, society, politics and the economy that allows individuals to strengthen their cultural history of awareness [5][6]. The creative industry is a driver of value creation in the creative economy. In the process of creating creative values, the creative industry not only creates economic transactions, but also social and cultural transactions.

The general processes that occur in the creative value chain are commercialization creations, but each group of creative industries has a different creative chain. The definition of the creative industry itself according to the Ministry of Trade in the book Indonesian Creative Economy Development 2025 (2008) is: "The ability of the creative industry in utilizing the creativity, skills and talents of individuals to create prosperity and employment through the creation and utilization of the individual's creative and creative power " The Indonesian Creative Economy Agency has issued the latest subsectors of the creative industry, namely as many as 16 creative industry sub-sectors, including architecture; interior design; visual communication design; product design; fashion; films, animations, and videos; photography; craft; culinary; music; application and game developer; publishing, advertising, performing arts, fine arts, and television and radio. (Perpres No. 72 of 2015).

The concept of creative tourism was initially based on experiences related to traditional cultural areas and learning creativity. newer models have been based on the integration of tourism and the creative industry as a whole, which involved not only consumers but also producers, policy makers, and knowledge institutions. Creative sectors such as design, fashion, games, and animation now provide access to new markets and demand diversification (OECD, 2014).

\subsubsection{Local Economic Development \& Government Policy}

The World Bank describes the economic process carried out jointly by governments, businessmen and nongovernmental organizations to create better conditions for economic growth and job creation at the local level. Local Economic Development (LED) can be defined as a process in which partnerships between local governments, community-based groups, and the private sector are established to manage existing resources to create jobs and encourage a good economy in a particular region [7]. It emphasizes local control, using local human potential, institutions and physical abilities. Local economic development has the initiative to mobilize actors, organizations, and resources, develop new institutions and local systems through dialogue and strategic action. Local economic development is a process in enhancing the ability of human resources to create superior products, market search, transfer of knowledge and technology, and development of small industries and business activities on a local scale [8].

In the perspective of local economic development, the 
interaction between tourism and the region becomes fundamental. Tourism has become one of the most important industries. This is based on globalization and its role in global development, while its dimensions are local and connected to the company's local network. Regional economic development models, institutions must be aware of the problems and risks of poorly implemented programs and sustainable interventions in the region. Government intervention must state the route for local economic development, especially for what concerns sustainability. Tourism is an economic activity that helps local areas to develop towards tourist destinations. with that there are many effects that occur, some things are linear consequences such as the emergence of hotels and the travel industry. Possible positive effects are an increase in local welfare and economic growth, while other effects are related to the environment and the context of a social culture that may be affected by the existence of a new culture and lifestyle.

\subsection{Research Methods}

This study uses a descriptive analysis method, where this method is used to explain a phenomenon that occurs. Descriptive methods are used to describe, interpret a phenomenon, for example, conditions or relationships that exist, opinions that develop, by using scientific procedures to answer actual problems. This study also uses a narrative method which is a research strategy in which researchers investigate the lives of individuals and ask one or a group of individuals to tell their lives.

The unit of analysis in this study are people who know, relate, and being an actor from Jaranan's creative arts show industry, is expected to provide information. Determination of this informant was obtained by applying the population, meaning that all parties in the study played a role as research targets. Informants are selected based on their knowledge of the creative industry, tourism and Jaranan arts in Kediri City. Based on this, the informant to be chosen is:

a. Head of Cooperative and MSME Services

b. Head of Kediri City Culture, Tourism, Youth and Sports Department

c. The owner of the Jaranan art group

d. Chairman of the Association of Artists of Jaranan Wahyu Kridha Budaya

e. Barongan craftsmen

Data collection techniques in this study use interviews, documentation, and observation. Data analysis technique at the researchers have 5 phases: the first phase is to process data obtained from field interviews, from interviews selected and adapted to the research needs; the second stage of data that has been processed will be adjusted to the document; the third stage is After deciphering the research data, this process is commonly known as validation and reduction; the fourth stage is to interpret the findings of the research results using argumentative exposure; as the final step in the process of verifying the findings of research results with relevant theories or concepts.

\subsection{Results and Discussion}

\subsubsection{Development of Creative Industries in Kediri City}

Leading MSMEs in the City of Kediri are included in the industry because they have special characteristics and are able to absorb workers from the City of Kediri. The utilization of the local economy in MSMEs is not fully absorbed, because for some MSMEs the production materials still take from outside the City of Kediri. Data from MSME Kediri City has shown that Jaranan art dance is the most number of performing arts in the city of Kediri with a total of 113 Groups that already have a parent number, Jaranan art becomes performing arts most popular in the City of Kediri. The development of Jaranan's art is growing rapidly from year to year. This is confirmed by Yudhi's statement as one actor in Jaranan art since 1972 that, "In the past, my initial entry in Jaranan group, was comprised of 60 groups, now there are nearly 120 groups Kediri”.

The attraction of Jaranan art has resulted in more and more people joined the Jaranan group, even Yudhi revealed, "Every group usually consists of 20-30 people, but to find 100 Jaranan players from Kediri City took a quick because a lot of people Kediri willing to perform during performances Jaranan, even some people dial directly to me and because of the number of players is enough, and some youth to be willing as a crew as well as the investigators only when there is Jaranan art dance this appear".

Judging from the absorption of labor in Kediri City, in the arts group, Jaranan absorbs enough labor. That easel in the draw of each person in the group Jaranan is, all personnel in Jaranan have other work to meet their needs. For the distribution of pension funds from the Jaranan show, each player usually gets USD 3,00

- USD 4,00 while Nayaga as a gamelan player usually gets USD 5,00 to Rp. 7,00, but not all Jaranan groups share the same nominal. According to Hari Pratondo "Now that the Jaranan group divides the application from the show transparently, all members of the group know how many penances will be paid at that time and what costs are incurred so that each group member knows what they get". Because of the income from the small jaranan shows, every player plays when This certainly has other jobs, most of these officials work as factory workers, as expressed by Yudhi namely: "Jaranan cannot be used as a job now, every player must have another job outside the road, there are factory workers, construction workers. So when there is a performance, it cannot be a day or two for preparation, at least a week before".

\subsubsection{Side effects from Jaranan Art}


Preservation or development of Jaranan Art provides another economic impact. Presence local street art, building representative and heritage culture in maybe have an impact on an amount in a creative industry, located in the Local Labor System [9]. Jaranan art can absorb workers directly, namely the players, or also supporting industries, including Barongan carving craftsmen in Lirboyo Village and whip craftsmen in Jagalan Village. The supporting industry grew because buyers of the Jaranan equipment were not limited to the Jaranan group but the people who were hobbies with Jaranan arts also bought the Jaranan equipment as a collection. The government has been started to measure room scope from economy creative as indicator important health economy change in the economy have been push asset creative to the center of life economy [10].

\subsubsection{Strategies in Local Economic Development and Creative Economy in Jaranan Art As a Tourist Attraction}

Creativity will destabilize the tourist destination to create innovative products that will provide added value and higher competitiveness compared to other tourist destinations [11]. The policy of the Kediri City Government for management Jaranan art dance which is one of the icons of the creative industry are as follows :

a. Give the number of the member

According to the statement from Yudha "Since 2013, every Jaranan group has been given a member number so that when the government has a government event, the number of members of Jaranan is known in Kediri City". Besides having a member number, the government must also encourage the Jaranan Artists to have a legal entity. Low level of public awareness of legal entity ownership, making businesses do not have definite legality [12].

b. Include in the annual event of the City of Kediri

Since 2010, the government of Kediri has scheduled various events that must have included Jaranan art dance, this was expressed by Nur Muhyar, "This year there are a number of events that include Jaranan arts such as Grebeg Sura, Jaranan Nusantara Performance, Jaranan Parade, and techno Jaranan shows. And these events will become the annual agenda of Kediri City".

\section{c. Patenting Jaranan Art}

Nur Muhyar, "The government has tried to patent Jaranan art, but because Jaranan art has a lot in common with the Kuda Lumping art in various regions and Jaranan in Kediri does not have a special grip, so to look for failures". Strengthen rights copyright (patent) or extend period the time no will on an automatic translated to more creative output level high if the motivation for involvement in production very low creative [13].

Hari Pratondo As Chair of the Jaranan City Community Kediri Wahyu Kridha Budaya, have a suggestion that Jaranan art dance stays awake and able to travel the attraction of Kediri City:

\section{a. Appearance Arrangement}

The first thing that must be done in the effort to preserve the Jaranan art is structuring the appearance. As a determinant of a show is in demand or not is the community itself, because people are consumers or users (responders) from entertainment services. The Jaranan group that has received responses is a group who have certain advantages such as good looks, competitive prices, and good marketing. Among these conditions is a good appearance become the main (Huda, 2016).

\section{b. Kediri's identity and icon}

The strategic plan for local economic development is usually carried out by the local government in relation to the public and the private sector. Implementation is done by the public, private and nongovernmental sector in accordance with their capabilities and power [14]. The prominence of Jaranan as the identity and ikon Kediri can be done by making Jaranan as a local ornamental variety that appears in batik and ornamental ornaments of public building architecture[15]. Jaranan pictures should be used as souvenirs with attractive designs that can attract the interest of the community. Kediri has been synonymous with Jaranan, there are many craftsmen and accessories sellers Jaranan's unique souvenirs of the area.

\section{c. Place of Show}

Jaranan art dance indeed continues has been featured in several attractions in Kediri City, but all spectacle without adequate facilities, and the lack of bench seating for the audience to enjoy the show comfortably. Three motives for visiting tourist sites are security, comfort and location facilities so that tourists can get experience enjoying art performances [6]. According to Nur Muhyar, Head of the Youth and Sports Tourism Culture Office, "Actually, in Selomangleng Cave, there is already a place for artists to show their work, especially for Jaranan art, it is scheduled once a month there will be Jaranan shows".

d. Enter the School Curriculum

As in the area of Bali where local dances are taught in schools so that young racers will know and participate in preserving. Or technology development can be developed so that Jaranan can be displayed not normal [8]

e. Media Publication.

Digitalization is way new to create, produce, disseminate, and open art and culture, as exemplified by open source and social media [16]. With the development of the digital world, Jaranan Art should get its own publication media \& managers are also required to be more creative in promoting through digital media.

\section{CONCLUSION}


The government has now begun to focus on the creative economy industry, this is realized by the establishment of the Creative Economy Agency in 2015. Jaranan art dance as one of the creative industries in the City of Kediri is able to survive between the development of technology that has entered the life of society. Jaranan art has now become a part of the life of the people of Kediri, this is evident from year to year the number of jaranan groups is increasing, besides the existence of jaranan also attracts the community to participate in the jaranan group to become dancers in the jaranan when shown.

The lower income as a jaranan player, makes players only consider playing jaranan as a hobby or additional income. The development of the local economy with the development of the art of jaranan is very much felt in other business sectors, in addition to the increasing number of craftsmen in accessories and accessories, street vendors also get a good impact from the crowds of the spectators during the jaranan performances. This shows that the jaranan show has an attraction and a large number of viewers also has an impact on the sale of food and drinks around the show area. There is still a need for good cooperation between the government, artists, and the community so that Jaranan art can maximally become a tourist attraction. By having a permanent schedule and show location coupled with adequate access, it is hoped that Jaranan's art can continue to grow and attract many local and foreign tourists.

\section{ACKNOWLEDGMENT}

This research was supported by Simlitabmas Grant Program, with "Penelitian Dosen Pemula" sceme fiscal year 2020. Author also thanks to Kadiri University for giving support completing this reaearch. We acknowledgment to all our family and colleges whosw motivate us during process of this research.

\section{REFERENCES}

[1] N. Boccella and I. Salerno, "Creative Economy, Cultural Industries and Local Development," Procedia - Soc. Behav. Sci., vol. 223, pp. 291296, 2016.

[2] A. Biran, Y. Poria, and G. Oren, "Sought experiences at (Dark) heritage sites," Ann. Tour. Res., vol. 38, no. 3, pp. 820-841, 2011.

[3] J. S. Podoshen, G. Yan, S. A. Andrzejewski, J. Wallin, and V. Venkatesh, "Dark tourism, abjection and blood: A festival context," Tour. Manag., vol. 64, pp. 346-356, 2018.

[4] D. Light, "Progress in dark tourism and thanatourism research: An uneasy relationship with heritage tourism," Tour. Manag., vol. 61, pp.
275-301, 2017.

[5] S. Bintarti and E. N. Kurniawan, "A Study of Revisit Intention : Experiential Quality and Image of Muara Beting Tourism Site in Bekasi District," Eur. Res. Stud. J., vol. XX, no. 2, pp. 521-537, 2017.

[6] B. J. Yan, J. Zhang, H. L. Zhang, S. J. Lu, and

Y. R. Guo, "Investigating the motivation- experience relationship in a dark tourism space: A case study of the Beichuan earthquake relics, China," Tour. Manag., vol. 53, pp. 108-121, 2016.

[7] A. H. J. (BERT) Helmsing, "Local Economic Development: New Generations of Actors, Policies and Instruments for Africa," vol. 76, no. July, pp. 67-76, 2001.

[8] B. Dewandaru and N. Purnamaningsih, "Strategi Dalam Memajukan Industri Kreatif Sebagai Daya Tarik Wisata," J. Ekon., vol. 1, no. 2, pp. 170-187, 2016.

[9] A. Española de Ciencia Regional España Sánchez Serra and D. Sánchez Serra, "Location determinants of creative industries' firms in Spain," Investig. Reg. - J. Reg. Res., vol. 34, no. 34, pp. 23-48, 2016.

[10] S. J. Tepper, "Creative assets and the changing economy," J. Arts Manag. Law Soc., vol. 32, no. 2, pp. 159-168, 2002.

[11] Ö. K. Yozcu and O. İçöz, "A Model Proposal on the Use of Creative Tourism Experiences in Congress Tourism and the Congress Marketing Mix," vol. 8, no. 3, pp. 105-113, 2010.

[12] Y. P. Putra and B. Heryanto, Pemetaan Kepemilikan Badan Hukum Dan Tingkat Penggunaan Teknologi Informasi Pada Umkm, vol. 2, no. 2. 2017.

[13] G. Doyle, "Creative economy and policy," Eur. J. Commun., vol. 31, no. 1, pp. 33-45, 2016.

[14] \& M. F. Swinburn G, Goga S, "Local Economic Development: a Primer Developing and Implementing Local Economic Development Strategies and Action Plans," Local Econ. Dev. Prim., 2006.

[15] A. Biran, Y. Poria, and G. Oren, "Sought Experiences At (Dark) Heritage Sites," Ann. Tour. Res., vol. 38, no. 3, pp. 820-841, 2011.

[16] C. Weckerle, R. Page, and S. Grand, "From the Creative Industry to the Creative Economies: Excerpt from the Creative Industry Report," Zürcher Hochschule der Künste, 2016. 